\title{
Pollination of Four Sumatran Impatiens Species by Hawkmoths and Bees
}

\author{
Makoto KATO Biological Laboratory, Yoshida College, Kyoto University, Sakyo, Kyoto 606, Japan \\ Takao ITINO Laboratory of Applied Entomology, Faculty of Agriculture, Kagawa University, \\ Kita-gun, Kagawa 761-07, Japan \\ Mitsuru HOTTA Department of Biology, Faculty of Science, Kagoshima University, Kagoshima \\ 890, Japan \\ Tamiji INOUE Center for Ecological Research, Kyoto University, Shimosakamoto, Otsu 520-01, Japan
}

\begin{abstract}
Flowering patterns and pollination syndromes were compared among four sympatric Impatiens species (Balsaminaceae) in tropical montane rain forests in Sumatra, Indonesia. Pink flowers with long filiform spurs of $I$. platypetala produced nectar of $26 \%$ sugar both in the daytime and at night and were pollinated by crepuscular hawkmoths, Macroglossum corythus. Yellow flowers with gradually tapering spurs of $I$. korthalsii, I. talangensis and I. eubotrya produced nectar of 34-39\% sugar, mainly in the daytime, and were pollinated by two specialized long-tongued anthophorid bees and an unusually long-tongued halictid bee. Spur morphology essentially determined nectar accesibility. Although the three Impatiens species partially shared the three bee species, they partitioned their pollinators by differing in sites of pollen deposition on the bee's bodies. The low pollinator visitation rates per day were compensated by the extended flowering period of the four species. Nectar robbing by two anthophorid bee species was observed, for the first time in Southeast Asia.
\end{abstract}

Key Words: Impatiens / Sumatra / pollination / Halictidae / Anthophoridae

Deep flowers are thought to have coevolved with long-tongued, nectar-feeding organisms in various ecosystems in the world (Darwin, 1862). Many flowers having long-tubed or -spurred corollas are visited almost by long-tongued bumblebees and hawkmoths in the temperate zone (Heinrich, 1979), and by euglossine bees, hummingbirds and hawkmoths in the neotropics (Janzen, 1971; Dressler, 1982; Ackerman et al., 1985; Roubik 1989). In the palaeotropics, there are many deep flowers especially on the forest floor, whereas detailed analyses on the pollination syndrome have not yet been done.

In general, Impatiens flowers (Balsaminaceae) have long-spurred sepals which secrete nectar. The spur structure of Impatiens is excessively prone to vary (Hooker, 1874). In the palaeotropics, there are more Impatiens species than in the temperate zone, where most Impatiens species are mainly pollinated by bumblebees (Heinrich, 1979; Rust, 1979; Kato, 1989). In Africa, there are 109 morphologically diverse Impatiens species, and out of these, 58 species were pollinated by butterflies, three by moths, 27 by birds and 21 by bees (Grey-Wilson, 1980).

Mountain area of Southeast Asia is also a center of diversification of Impatiens (Miquel, 1862; Ridley, 1922; Van Steenis, 1972). In Sumatra, Indonesia, 29 species are reported by Grey-Wilson (1989), and even in the province of Sumatera Barat 16 are found by Hotta (1989). This remarkable diversification is thought to be due to isolation by drier regimes (Grey-Wilson, 1989) or to sympatric speciation caused by polyploidy in chromosome number (Okada, 1989). In order to understand the diversification process, we need more information 
on pollination and reproduction ecology of these tropical Impatiens.

In this paper, We report flowering patterns and pollination syndromes of four Impatiens species in the tropical montane forests in Sumatra. First, we compare nectar secretion patterns of the four species. Secondly, we describe four effective pollinators by comparing morphological characters of flowers and flower visitors. Furthermore, the pattern of pollinator visits to flowers and the effect of their behavior on seed set are analyzed. Pollination syndromes of deep flowers and long-tongued bees are also discussed among the three tropical regions.

\section{MATERIALS AND METHODS}

In and beside primary forests of Mt. Gadut and Mt. Talang areas in the province of Sumatera Barat, Sumatra, Indonesia, we found seven Impatiens species at elevations between 400 and $1800 \mathrm{~m}$ (Hotta, 1989). Impatiens platypetala has pink (rarely white) flowers, and the others have yellow flowers. Intensive field observations were carried out at Airsirah and Alahanpanjang (Fig. 1). There, four species, I. platypetala Lindley, I. korthalsii Miquel, I. talangensis Hotta, nom. nud. and I. eubotrya Miquel were relatively abundant. Airsirah was covered with a montane primary forest at an elevation of $950 \mathrm{~m}$. The mountain slopes near small streams were covered with the vegetation of Saurauja spp. (Actinidiaceae), Villebrunea rubescens (Urticaceae) and others. Impatiens korthalsii were scattered in the forest understory near streams and I. platypetala grows in clumps in light gaps along the streams and/or road side open places. Alahanpanjang is located along a stream on the west slope of an active volcano, Mt. Talang, at an elevation of $1300 \mathrm{~m}$. The study site is covered with primary and secondary mountain forests, the vegetation of which was largely the same with that of Airsirah. Along streams, three Impatiens species were abundant and partly grew together: $I$. korthalsii and $I$. talangensis were sparse, but I. eubotrya occurred in clumps.

To investigate the temporal patterns of flowering and the nectar production of Impatiens, at least five inflorescences were bagged with nylon nets to exclude visitors on January 11, 1988 at Airsirah, and on January 14, 1988 at Alahanpanjang. We estimated the nectar volume in each flower as a function of the depth of nectar in a spur. During the observations the depth of nectar of bagged flower was measured by backlighting. Simultaneously, unbagged flowers

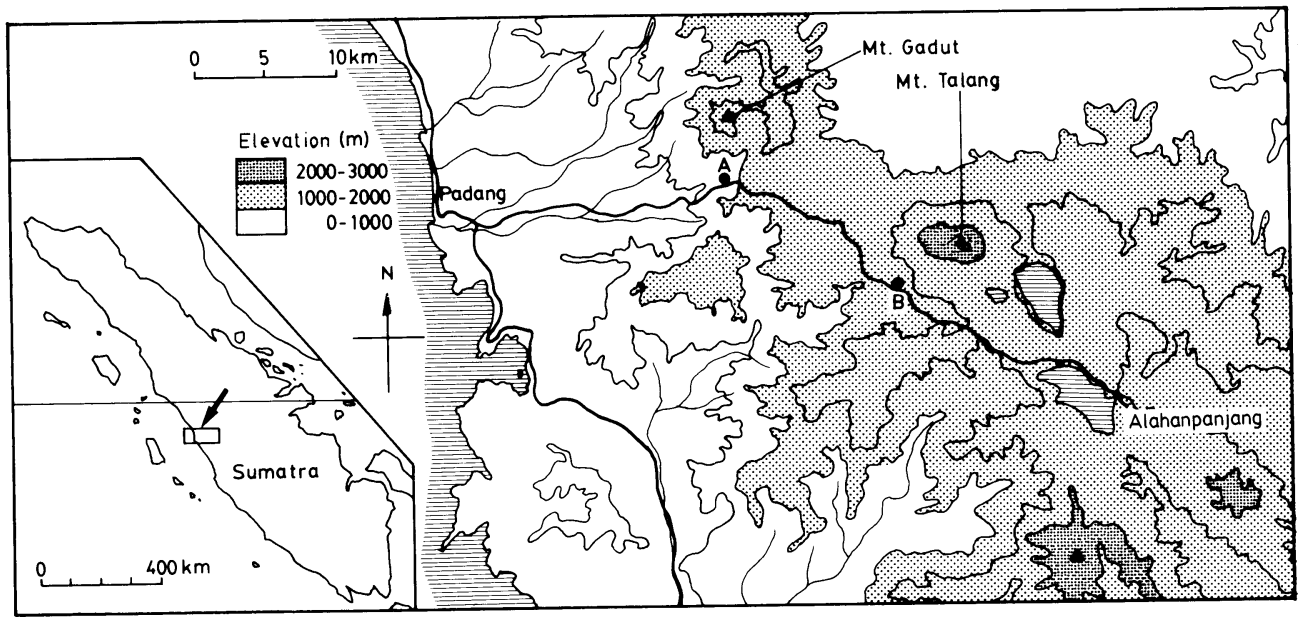

Fig. 1. The study sites (A, Airsirah; B, Alahanpanjang) in the province of Sumatera Barat and its location in Sumatra (inset). 
were randomly sampled and the depth and volume of nectar were measured. At the end of observations, flowers were dissected to determine the relationship of the two variables. Measurements were made at about 5-hour intervals for $>22$ hours after flower opening. The nectar sugar concentration (weight/weight) was measured with a refractometer (Bellingham Stanley Ltd.). Bagged and unbagged inflorescences were sampled on 30 January 1988 to record fruitand seed-set.

After preliminary observations and a haphazard collection of visitors to Impatiens during 21 - 31 December 1987, continuous periods of observation of insect visitors at Impatiens flowers were carried out from 6 to 30 January 1988. For each Impatiens, we selected a patch of flowering plants. We sat beside the patch for $>8$ hours to record the timing of visits, the flight paths of visitors between the flowers, and the time spent on each flower. Air temperature, relative humidity and light intensity were measured simultaneously. The temporal pattern of pollinator visits to flowers of I. platypetala, I. korthalsii and I. eubotrya were observed on 7-8, 12 and 15 January 1988, respectively. For I. talangensis, we only observed and collected pollinators for about 4 hours on 15 January 1988. All captured insects were examined for pollen with a microscope.

\section{RESULTS}

\section{Floral morphology and flowering}

The four Impatiens were distinct in their arrangement of petals and sepals, disposition of the peduncle and structure and curvature of the spur (Fig. 2). I. platypetala had a flattened flower with an erect dorsal petal and a shallow lower sepal, abruptly constricted into a long filiform spur. The others were slender funnel-type flowers with a hooded dorsal petal. The lower sepal of $I$. korthalsii and I. talangensis was shallowly boat-shaped, gradually tapering into a slightly curved spur, but that of I. eubotrya was narrowly sac-shaped and abruptly constricted into an incurved spur. The lower petals of I. korthalsii and I. talangensis were extended well beyond the tip of the lower sepals, thus forming prominent lips, but those of I. eubotrya were not so extended. The peduncle of I. eubotrya was distorted to leftside and the spur projected. Flower color was pink in I. platypetala and yellow in the other three species (Table 1). The

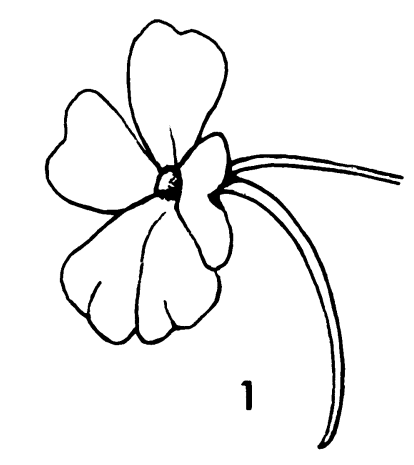

Fig. 2. Flowers of the four Impatiens species. 1, I. platypetala; 2, I. korthalsii; 3 , I. talangensis; 4, I. eubotrya.
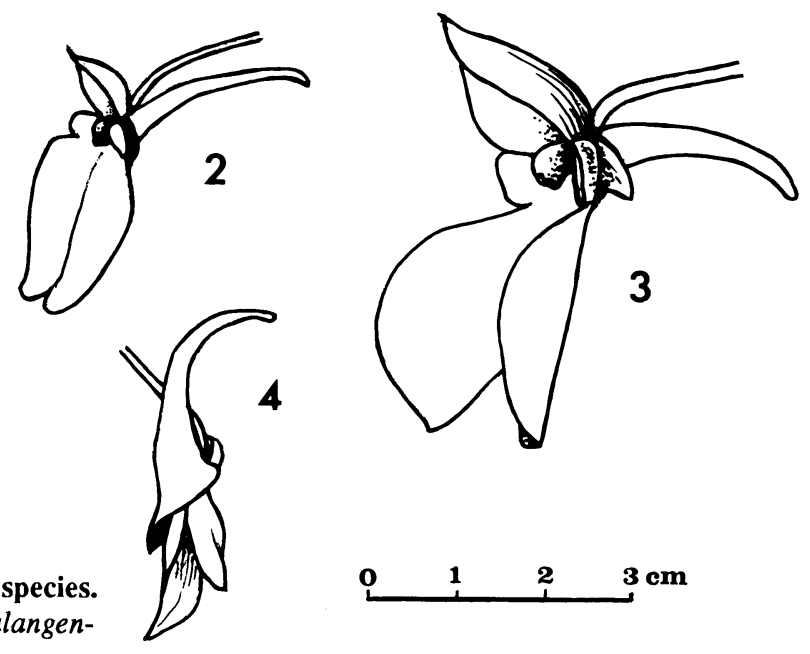
Table 1. Flower characters and nectar production patterns of the four Impatiens species. The mean is followed by the number of samples and the standard deviation (n, s.d.).

\begin{tabular}{lcccc}
\hline Characters & \multicolumn{4}{c}{ Impatiens species } \\
& platypetala & korthalsii & talangensis & eubotrya \\
\hline Flower color & pink or white & yellow & yellow & yellow \\
Length of spur $(\mathrm{mm})$ & $31.5(18,2.0)$ & $21.7(14,2.0)$ & $22.9(7,1.0)$ & $24.0(9,2.7)$ \\
Flowering duration (days) & $3.8(12,0.6)$ & $2.7(9,0.4)$ & $4.1(2,0.5)$ & $1.8(58,0.6)$ \\
Sugar concentration $(\%)$ & $26.1(21,7.1)$ & $37.9(30,6.3)$ & $33.8(2,8.8)$ & $39.4(58,3.2)$ \\
Nectar production rate $(\mu 1 / \mathrm{h})$ & & & & \\
Daytime (06:00-18:00 h) & 0.047 & 0.085 & 0.176 & 0.181 \\
& $(14,0.025)$ & $(11,0.061)$ & $(10,0.061)$ & $(25,0.086)$ \\
Night $\quad(18: 00-06: 00 \mathrm{~h})$ & 0.039 & 0.024 & 0.093 & 0.049 \\
& $(11,0.015)$ & $(9,0.027)$ & $(7,0.054)$ & $(14,0.039)$ \\
\hline
\end{tabular}

spur length (we call the lower sepal the spur hereafter) was longest in I. platypetala followed by I. eubotrya, I. talangensis and I. korthalsii (Table 1). The spurs of the four Impatiens species were different not only in length but also in shape. Relationships between the depth ( $x$ $\mathrm{mm})$ and the volume $(\mathrm{y} \mu \mathrm{l})$ of nectar stored in spurs of the four Impatiens species were well expressed by power functions: $\mathrm{y}=0.0121 \times 1.73(\mathrm{r}=0.92)$ for I. platypetala; $\mathrm{y}=0.00893 \mathrm{x}^{2.09}$ $(\mathrm{r}=0.90)$ for $I$. korthalsii; $\mathrm{y}=0.00472 \mathrm{x}^{2.46}(\mathrm{r}=0.98)$ for I. talangensis; $\mathrm{y}=0.0408 \mathrm{x}^{1.87}(\mathrm{r}=0.96)$ for I. eubotrya.

These Impatiens species were perennials which bloomed all the year round. Anthesis of $I$. platypetala usually occurred at night whereas the others opened in daytime. Flowers of all four species were protandrous and the male phase (stigma embedded under androecium) lasted longer than the female phase (stigma protruding from androecium or androecium fallen); the functional sex ratio was biased to males $(0.6-0.8)$. The mean life of a flower of $I$. platypetala was four days whereas those of the other species were two to three days (Table 1).

\section{Nectar production}

Each flower produced nectar steadily through its life. The sugar concentration of $I$. platypetala was significantly lower $(\mathrm{p}<0.001)$ than those of the others (Table 1$)$.

The nectar production rate in daytime was highest (ca. $0.2 \mu \mathrm{l} / \mathrm{h}$ ) in $I$. eubotrya and was followed by I. talangensis, I. korthalsii and I. platypetala (Fig. 3). In I. platypetala, nectar production rate was not significantly different between daytime $(06: 00-18: 00 \mathrm{~h})$ and night $(18: 00-06: 00 \mathrm{~h})(\mathrm{df}=23, \mathrm{t}=1.25, \mathrm{p}>0.1)$. On the other hand, in I. korthalsii, . talangensis and I. eubotrya, nectar production was higher in daytime than at night (I. korthalsii at Airsirah, $\mathrm{df}=18, \mathrm{t}=1.94, \mathrm{p}<0.1 ; I$. korthalsii at Alahanpanjang, $\mathrm{df}=17, \mathrm{t}=1.89, \mathrm{P}<0.1 ; I$. talangensis, $\mathrm{df}=15, \mathrm{t}=1.86, \mathrm{p}<0.1 ;$ I. eubotrya $, \mathrm{df}=37, \mathrm{t}=6.822, \mathrm{p}<0.001)$.

In I. platypetala the mean nectar volume of unbagged flowers (NU) was not significantly different from that of the bagged flowers (NB) both in the morning and evening (Table 2). In contrast, in $I$. korthalsii, NU was significantly less than NB in the morning and evening, and $\mathrm{NU}$ in the evening was significantly less than $\mathrm{NU}$ in the morning $(\mathrm{df}=18, \mathrm{t}=2.43, \mathrm{p}<0.05)$. In I. talangensis, NU was significantly less than NB in the evening (Table 2). In I. eubotrya, $\mathrm{NU}$ was significantly less than NB in the afternoon $(13: 00 \mathrm{~h} ; \mathrm{df}=20, \mathrm{t}=13.87, \mathrm{p}<0.001)$ and evening but not in the morning (Table 2 ), and $\mathrm{NU}$ in the afternoon was significantly less than $\mathrm{NU}$ in the morning $(\mathrm{df}=22, \mathrm{t}=7.69, \mathrm{p}<0.001)$. These data suggest that the nectar of the last three species was consumed by diurnal visitors. 
Table 2. Comparison of the mean (n, s.d.) nectar volume (ml) between bagged and unbagged flowers of the four Impatiens species, by t-test.

\begin{tabular}{|c|c|c|c|c|c|c|}
\hline \multirow{2}{*}{$\begin{array}{l}\text { Impatiens } \\
\text { species }\end{array}$} & \multicolumn{3}{|c|}{ Morning (08:00 h) } & \multicolumn{3}{|c|}{ Evening $(16: 00 \mathrm{~h})$} \\
\hline & Bagged & Unbagged & $\mathrm{t}$ & Bagged & Unbagged & $\mathrm{t}$ \\
\hline platypetala & $\begin{array}{l}1.95 \\
(11,0.61)\end{array}$ & $\begin{array}{l}1.61 \\
(9,1.78)\end{array}$ & 0.38 & $\begin{array}{l}1.82 \\
(11,0.56)\end{array}$ & $\begin{array}{l}1.63 \\
(7,1.63)\end{array}$ & 1.09 \\
\hline korthalsii & $\begin{array}{l}1.98 \\
(10,0.92)\end{array}$ & $\begin{array}{l}1.46 \\
(9,1.78)\end{array}$ & $3.24^{*}$ & $\begin{array}{l}1.72 \\
(9,0.69)\end{array}$ & $\begin{array}{l}0.99 \\
(10,0.79)\end{array}$ & $5.49 * *$ \\
\hline talangensis & - & - & - & $\begin{array}{l}5.51 \\
(3,0.73)\end{array}$ & $\begin{array}{l}1.20 \\
(13,1.21)\end{array}$ & $18.09 * * *$ \\
\hline eubotrya & $\begin{array}{l}1.98 \\
(10,1.26)\end{array}$ & $\begin{array}{l}1.68 \\
(12,1.47)\end{array}$ & 1.87 & $\begin{array}{l}2.22 \\
(8,1.67)\end{array}$ & $\begin{array}{l}1.54 \\
(11,1.22)\end{array}$ & $3.52 *$ \\
\hline
\end{tabular}
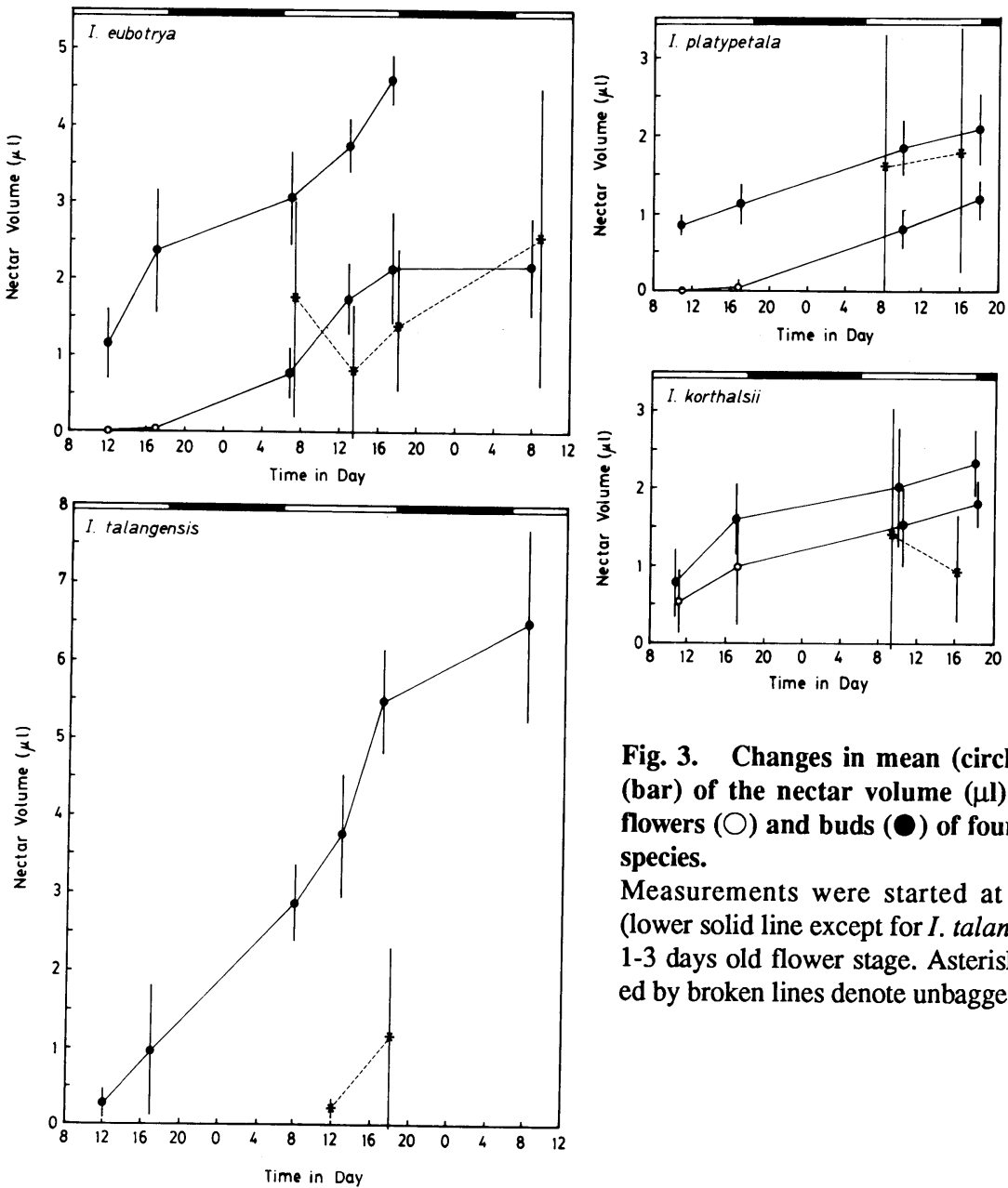

Fig. 3. Changes in mean (circle) and s.d. (bar) of the nectar volume $(\mu \mathrm{l})$ in bagged flowers $(\bigcirc)$ and buds $(O)$ of four Impatiens species.

Measurements were started at bud stage (lower solid line except for I. talangensis) and 1-3 days old flower stage. Asterisks connected by broken lines denote unbagged flowers.

\section{Insect visitors}

Twenty-one insect species were collected on flowers of the four Impatiens species (Table 3). Each Impatiens species had pollinators that could legitimately extract nectar left in the long spur. Excluding I. platypetala, which was pollinated by the hawkmoth, Macroglossum corythus, the other three species were pollinated by solitary bees of Halictidae and Anthophoridae. Although Thrinchostoma asianum belongs to Halictidae, considered to be a 
family of short-tongued bees, it had a long tongue $(15 \mathrm{~mm})$, and could extract nectar in the deep spur of $I$. korthalsii. Hairs on its thorax touched the androecium of $I$. korthalsii flowers during floral visits. Amegilla sumatrana, a medium-sized anthophorid bee with a long tongue, visited I. korthalsii and I. eubotrya. Amegilla sumatrana is placed in a subgenus Glossamegilla, which is characterized by brown pubescence and a long tongue (Brooks, 1988). Elaphropoda impatiens is also a medium-sized long-tongued anthophorid and is endemic to Sumatra (Lieftinck, 1944). This visited flowers of I. korthalsii, I. talangensis and I. eubotrya. Amegilla sumatrana also visited Cyrtandra sp. (Gesneriaceae) and E. impatiens visited Globba variabilis (Zingiberaceae) (Kato et al., 1989). All three bee species inhabited the understory of the rain forest and never visited flowers in the open habitats which were studied by Inoue et al. (1990).

Amegilla andrewsi (bearing shining blue bands on abdomen) sometimes landed on spurs of Impatiens flowers to rob nectar by perforating the tip of the spur with the mandibles. Protomelissa vulpecula, putatively a cleptoparasite of E. impatiens (Lieftinck, 1944), robbed nectar of $I$. korthalsii and $I$. eubotrya in a similar manner as $A$. andrewsi. Interestingly, $P$. vulpecula is a parasite of both the host bee $E$. impatiens and its main food source. Other small bees, such as Lasioglossum spp. and Ceratina sp. 1 were pollen thieves and secondary nectar

Table 3. Insect visitors, their lengths of forewings and proboscises, the mean numbers of visits per hour per flower patch of the four Impatiens species. Anthecological status follows Inouye (1980).

\begin{tabular}{|c|c|c|c|c|c|c|c|c|}
\hline \multirow{2}{*}{ ORDER Family } & \multirow{2}{*}{ Species } & & \multicolumn{4}{|c|}{$\begin{array}{l}\text { Mean number of visits per hour } \\
\text { Impatiens species }\end{array}$} & \multirow{2}{*}{$\begin{array}{l}\text { Antheco- } \\
\text { logical } \\
\text { status* }\end{array}$} \\
\hline & & $\begin{array}{l}\text { ore- } \\
\text { ing }\end{array}$ & $\begin{array}{l}\text { Probo- } \\
\text { scis }\end{array}$ & $\begin{array}{l}\text { platy- } \\
\text { petala }\end{array}$ & $\begin{array}{l}\text { korth- } \\
\text { alsii }\end{array}$ & $\begin{array}{l}\text { talang- } \\
\text { ensis }\end{array}$ & $\begin{array}{c}\text { eubo- } \\
\text { trya }\end{array}$ & \\
\hline \multicolumn{9}{|l|}{ LEPIDOPTERA } \\
\hline Sphingidae & Macroglossum corythus 3 & 34.3 & 44.0 & 0.08 & - & - & - & $\mathrm{Pn}$ \\
\hline Satyridae & Mycalesis marginata & 24.1 & 5.7 & - & 0.66 & - & - & Tn \\
\hline \multicolumn{9}{|l|}{ DIPTERA } \\
\hline \multirow[t]{2}{*}{ Syrphidae } & Episyrphus sp. & 7.9 & 1.1 & 1.43 & 0.43 & - & 0.09 & $\mathrm{Tn}$ \\
\hline & Baccha sp. & 8.0 & 1.0 & 0.14 & 0.33 & - & - & $\mathrm{Tp}$ \\
\hline \multicolumn{9}{|c|}{ COLEOPTERA } \\
\hline Mordellidae & Glipa sp. & 7.9 & - & - & - & - & 0.09 & $\mathrm{Tp}$ \\
\hline \multicolumn{9}{|c|}{ HYMENOPTERA } \\
\hline \multirow[t]{5}{*}{ Formicidae } & Crematogaster sp. 1 & - & - & - & 0.33 & - & - & $\operatorname{Tn}$ \\
\hline & Crematogaster sp. 2 & - & - & 0.14 & - & - & - & Tn \\
\hline & Pratrechina sp. & - & - & - & - & 0.33 & 0.45 & Tn \\
\hline & Monomorium pharaonis & - & - & - & - & 0.33 & - & $\mathrm{Tn}$ \\
\hline & Pheidole sp. & - & - & - & - & 0.33 & - & $\operatorname{Tn}$ \\
\hline Vespidae & Polybioides raphigastra & - & - & 0.33 & - & - & - & $\mathrm{Tn}$ \\
\hline \multirow[t]{4}{*}{ Halictidae } & Thrinchostoma asianum & 11.5 & 14.9 & - & 3.85 & - & - & Pn, Pp \\
\hline & Lasioglossum vulcanicum & 6.6 & 2.6 & - & 1.54 & 0.66 & - & $\mathrm{Tp}$ \\
\hline & Lasioglossum sp. 1 & 6.2 & 2.5 & - & 0.99 & - & 0.99 & $\mathrm{Tp}$ \\
\hline & Lasioglossum sp. 2 & 5.6 & 2.5 & 0.14 & - & - & - & $\mathrm{Tp}$ \\
\hline Anthophoric & dae Amegilla sumatrana & 11.0 & 16.4 & - & 0.57 & - & 0.91 & $\mathrm{Pn}, \mathrm{Pp}$ \\
\hline & A. andrewsi & 9.5 & 13.2 & 0.33 & 0.33 & - & 0.09 & Rpn, Pn \\
\hline & Elaphropoda impatiens & 10.2 & 16.5 & - & 3.08 & 1.33 & 3.91 & $\mathrm{Pn}, \mathrm{Pp}$ \\
\hline & Protomelissa vulpecula & 9.4 & 2.7 & - & 0.56 & - & 0.09 & Rpn \\
\hline & Ceratina sp. & 5.5 & 2.0 & 0.14 & - & - & - & Tp, Rsn \\
\hline & Braunsapis sp. & 6.0 & 2.3 & - & - & - & 0.09 & $\mathrm{Tp}$ \\
\hline
\end{tabular}

* Pn, pollinator searching for nectar; Pp, pollinator searching for pollen; Rpn, primary nectar robber; Rsn, secondary nectar robber; Tn, nectar thief; Tp, pollen thief. 


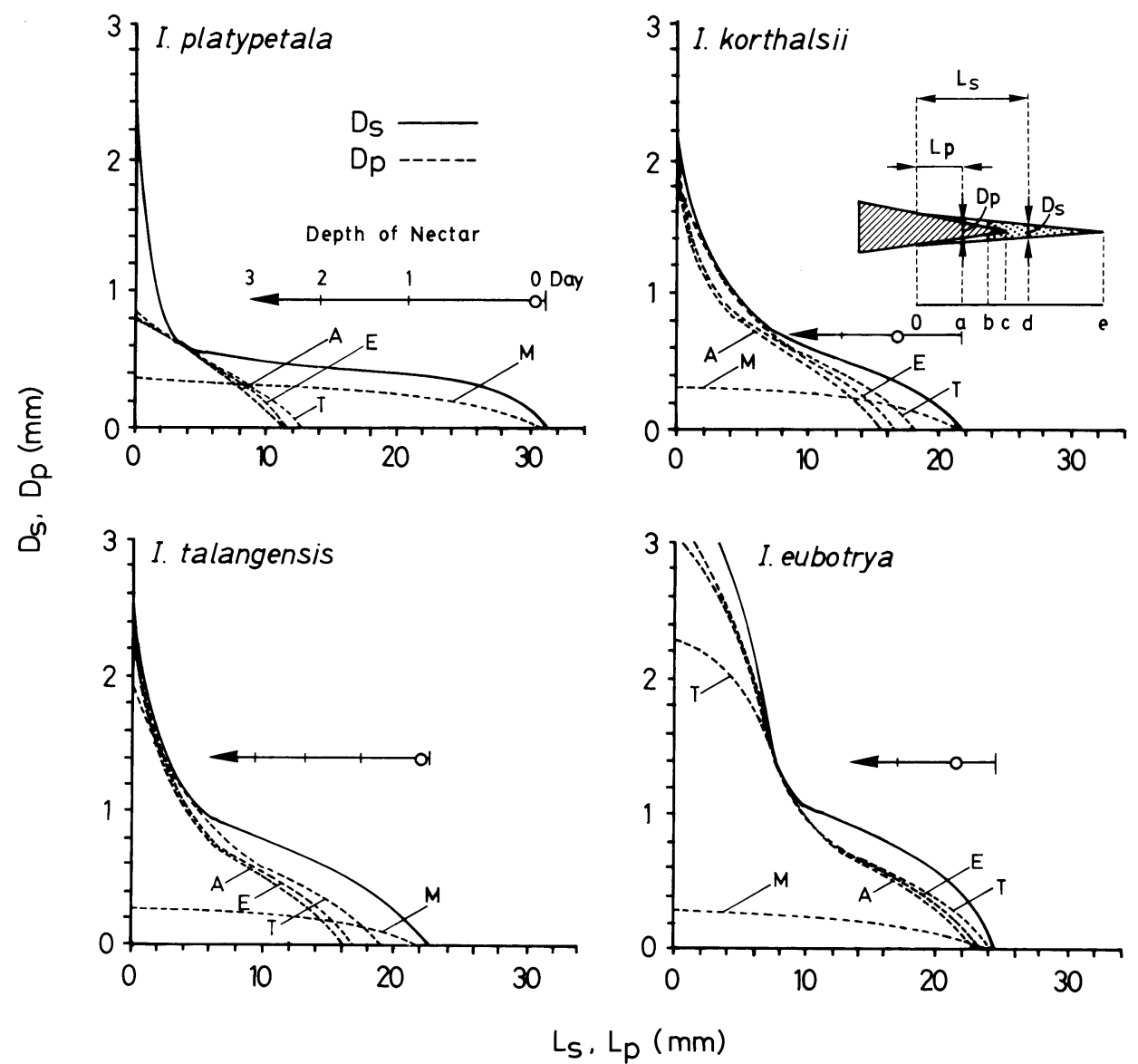

Fig. 4. The accessibility of spurs of the four Impatiens species by the four pollinator species. A, Amegilla sumatrana; E, Elaphropoda impatiens; T, Thrincostoma asianum; M, Macroglossum corythus. Ordinate denotes diameters of spur inner cavity (Ds) and pollinators' mouthparts (Dp) and abscissa denotes lengths of spur (Ls) and pollinator's mouthparts from entrance (Lp). Spurs and pollinators' mouthparts are shown by solid and broken lines, respectively. The upper right schema shows a vertical section of nectar (dotted area) in a spur and pollinator's mouthparts (shaded area). See text for details.

robbers. The percentage of perforated flowers was $8.3 \%(\mathrm{n}=24)$ on I. platypetala, $22.2 \%$ $(\mathrm{n}=36)$ on I. korthalsii at Airsirah; $20.8 \%(\mathrm{n}=24)$ on I. korthalsii, $20.0 \%(\mathrm{n}=15)$ for I. talangensis and $20.5 \%(\mathrm{n}=88)$ for I. eubotrya at Alahanpanjang. A pollinator tried to insert its mouthparts, and sometimes even the head into a spur as deep as possible. The accessibility of nectar to the three bee species was examined as follows (Fig. 4): Let us call Ls length of the spur from the spur mouth to point $d$, Ds the inner diameter of the spur at $d$ and e the length of the spur. The relationship between Ds and Ls of each Impatiens species shows that the spur cavity is not a simple cylinder but a swollen cone. When the pollinator inserted its mouthparts, it may not have access to all of the floral nectar. Calling Lp length of pollinator's mouthparts and Dp diameter of pollinator's mouthparts, Dp-Lp curve represents the mouthpart morphology. At the point that the Dp-Lp curve adjoins the Ds-Ls curve, the pollinator's insertion is thought to be blocked by the narrowness of the spur cavity. If the nectar is stored between $\mathrm{e}$ and $\mathrm{b}$ in a spur, the pollinator can extract nectar only between $\mathrm{c}$ and $\mathrm{b}$. 
The three bee species, $T$. asianum, A. sumatrana and E. impatiens, could exploit little nectar left in the slender spur of $I$. platypetala because their mouthparts were thicker than the spur diameter. The nectar of $I$. platypetala could be completely extracted only by $M$. corythus. Some portion of nectar of the three yellow Impatiens species could be extracted by the three bees, but their mouthparts did not reach the spur tip. Thrincostoma asianum, with a shorter proboscis than the other two anthophorids, could insert it deepest into spur because its mouthparts and head were more slender than the other two.

The posture of bees during nectar extraction determined the position of pollen attachment on a bee's body (Fig. 5). Pollen grains of $I$. korthalsii were attached to the dorsal part of thorax of $T$. asianum and to the clypeus, malar space, and rarely the dorsal thorax of A. sumatrana and E. impatiens. Pollen grains of $I$. talangensis were attached to the dorsal part of thorax of E. impatiens. On the other hand, pollen grains of I. eubotrya were attached to the ventral or lateral part of thorax of A. sumatrana and E. impatiens. The distortion of the peduncle and the particular curvature of the spur of $I$. eubotrya function to change the position of pollen attachment from that of the other Impatiens species.

\section{Temporal patterns of visits}

Only the hawkmoth, Macroglossum corythus, visited I. platypetala once at dawn (Fig. 6). We could not find any other insects visiting the flower legitimately in a total of 27 hours of observation. Impatiens platypetala, at the spur mouth, produced a thin liquid that was not nectar (volume $=3.17+1.60 \mathrm{ml}$ and sugar concentration $=2.20+2.71 \%$, mean + s.d.; $\mathrm{n}=8$ ). This liquid was found even during the bud stage. Pollen grains were often floating on this liquid. Thus, this liquid might help pollen grains adhere to the hawkmoth proboscis.

A flower patch of $I$. korthalsii was visited by both A. sumatrana and $T$. asianum several times per day (09:00-18:40 h, Fig. 7). Fast-flying males of E. impatiens visited 19 times per day but scarcely landed on the flowers (Fig. 7). These males are thought to come to the flowers for mating rather than solely to feed. The mean number of flowers visited by an A. suma-
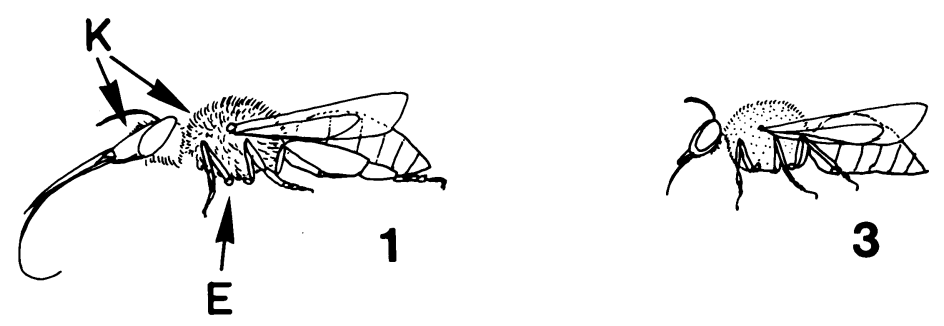

3
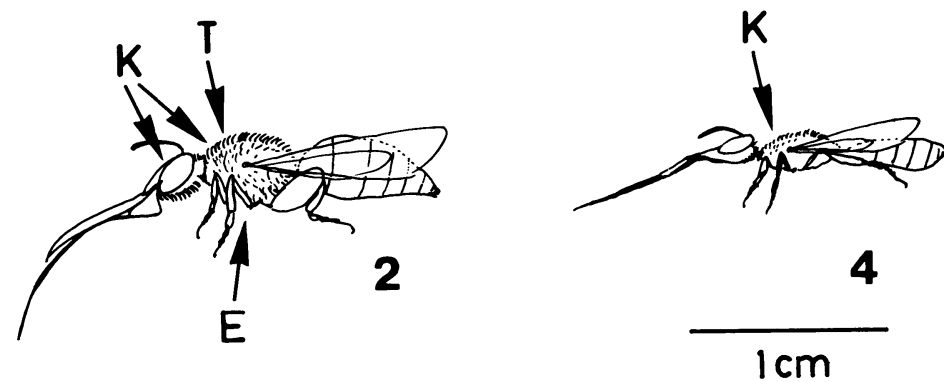

Fig. 5. Lateral view of the four bee species. 1, Amegilla sumatrana; 2, Elaphropoda impatiens; 3 , Protomelissa vulpecula; 4, Thrincostoma asianum. Arrows show the positions of pollen grains attached to bees' bodies: E, I. eubotrya; K, I. korthalsii; T, I. talangensis. 
trana female per visit to a patch was about 19 (about two thirds of flowers in the patch), and the mean time spent on a flower was about 1 second (Table 4). Amegilla sumatrana males were rare during our observation periods.

A flower patch of $I$. eubotrya was visited by females of both A. sumatrana and E. impatiens several times per day (07:00-18:30 h, Fig. 8). Elaphropoda impatiens females foraged more flowers per visit in a patch and stayed on a flower longer than $E$. impatiens males (Table 4). E. impatiens males flew swiftly and visited the patch frequently but they rarely landed on the flowers. The number of flowers visited by them per visit in a patch was usually one. Their activity increased at air temperature of $>20^{\circ} \mathrm{C}$.

As a result of bees' foraging, only a small part of flowers in a patch was visited by legitimate pollinators each day (Table 5). The frequency of pollinator visits to flowers of $I$. eubotrya may be underestimated because some effective visits by fast-flying males of $E$.

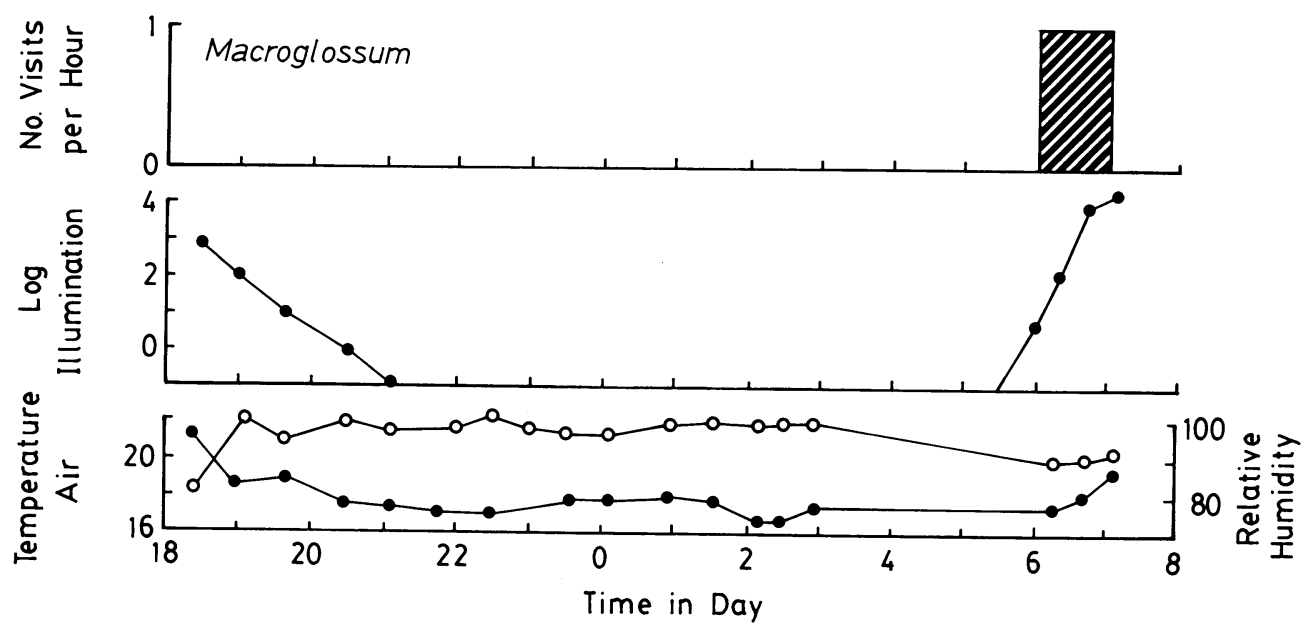

Fig. 6. Insect visits to an Impatiens platypetala flower patch and changes in light intensity (lx, logarithmic scale), air temperature $\left({ }^{\circ} \mathrm{C}\right.$; solid circle) and relative humidity (\%; open circle) at Airsirah on January 7-8, 1988.

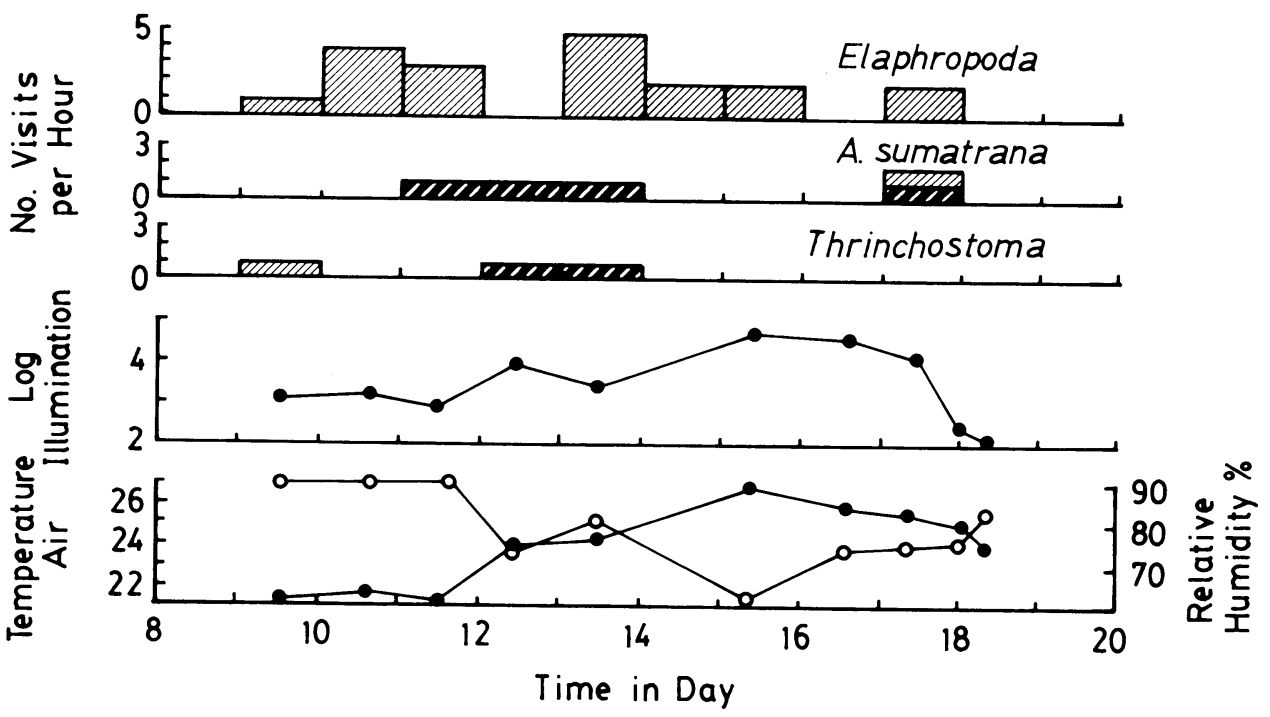

Fig. 7. Insect visits to an Impatiens korthalsii flower patch. Airsirah on January 12, 1988.

Thick striped and shaded columns denote probing-visits and approach-visits, respectively. 


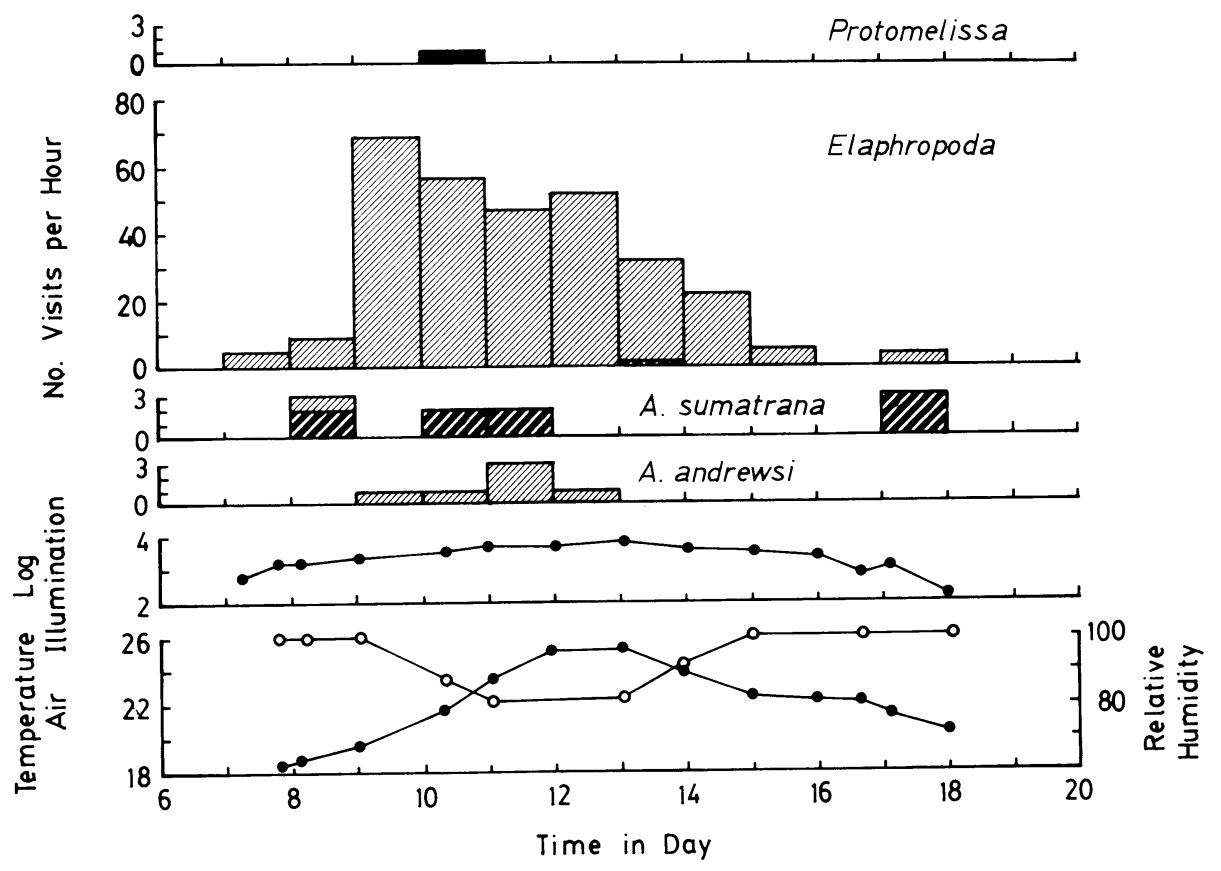

Fig. 8. Insect visits to an Impatiens eubotrya flower patch. Alahanpanjang on January 15, 1988. Thick striped, shaded and solid columns denote probing-visits, approach-visits and robbing-visits.

Table 4. Mean number of flowers visited per bout in a patch and the mean time spent on a flower by the four bee species.

\begin{tabular}{|c|c|c|c|c|c|c|c|c|c|}
\hline \multirow[t]{2}{*}{$\overline{\text { Pollinators }}$} & \multirow[t]{2}{*}{ Sexes } & \multirow[t]{2}{*}{$\begin{array}{l}\text { Impatiens } \\
\text { Species }\end{array}$} & \multirow{2}{*}{$\begin{array}{l}\text { Number } \\
\text { of } \\
\text { flowers } \\
\text { per } \\
\text { patch }\end{array}$} & \multicolumn{3}{|c|}{$\begin{array}{l}\text { Number of flowers } \\
\text { visited per bout } \\
\text { in a patch }\end{array}$} & \multicolumn{3}{|c|}{$\begin{array}{l}\text { Time spent } \\
\text { on a flower } \\
\text { (sec.) }\end{array}$} \\
\hline & & & & $\mathrm{n}$ & Mean & s.d. & $\mathrm{n}$ & Mean & s.d. \\
\hline Macrogrossum corythus & $\mathrm{F}$. & platypetala & 20 & 1 & 15.0 & - & 15 & 2.0 & 0.0 \\
\hline \multirow{2}{*}{ Thrincostoma asianum } & F. & korthalsii & 28 & 1 & 1.0 & - & 1 & 21.0 & - \\
\hline & M. & korthalsii & 28 & 10 & 1.1 & 0.3 & 12 & 3.3 & 3.9 \\
\hline Amegilla sumatrana & $\mathrm{F}$. & korthalsii & 28 & 9 & 19.4 & 11.9 & 99 & 1.1 & 1.0 \\
\hline \multirow[t]{2}{*}{ Elaphropoda impatiens } & F. & eubotrya & 41 & 9 & 2.7 & 2.2 & 24 & 2.7 & 2.3 \\
\hline & M. & eubotrya & 41 & 8 & 1.3 & 0.5 & 10 & 0.9 & 0.6 \\
\hline
\end{tabular}

Table 5. Frequency distribution of the number of visits that one flower receives per day and the probability that the flower is visited by pollinators once or more per day.

\begin{tabular}{|c|c|c|c|c|c|c|c|c|c|c|c|}
\hline \multirow{2}{*}{$\begin{array}{l}\text { Impatiens } \\
\text { Species }\end{array}$} & \multicolumn{7}{|c|}{ Number of visits } & \multirow[t]{2}{*}{$\mathrm{n}$} & \multicolumn{2}{|c|}{ No. of Visits } & \multirow{2}{*}{$\begin{array}{l}\text { Probability } \\
\text { of receiving } \\
\geqq 1 \text { visit } \\
\end{array}$} \\
\hline & 0 & 1 & 2 & 3 & 4 & 5 & 6 & & Mean & s.d. & \\
\hline platypetala & 80 & 15 & 0 & 0 & 0 & 0 & 0 & 95 & 0.16 & 0.37 & 0.16 \\
\hline korthalsii & 4 & 10 & 12 & 8 & 1 & 5 & 0 & 40 & 2.18 & 1.45 & 0.90 \\
\hline talangensis * & 2 & 2 & 1 & 0 & 0 & 0 & 0 & 5 & 0.80 & 0.84 & 0.60 \\
\hline eubotrya & 22 & 14 & 3 & 1 & 0 & 0 & 0 & 40 & 0.58 & 0.75 & 0.45 \\
\hline
\end{tabular}

* From a 4 hour observation and others from 12 hour observation.

impatiens might have been overlooked. The very low frequency of pollinator visitation at $I$. platypetala might be compensated by flower longevity ( 3.8 days, Table 1$)$ or by selfpollination (autogamy, Table 6). 
Table 6. Comparison of fruit-set between bagged and unbagged flowers, by Fisher's exact probability test.

\begin{tabular}{|c|c|c|c|c|}
\hline \multirow{2}{*}{$\begin{array}{l}\text { Impatiens } \\
\text { species }\end{array}$} & \multicolumn{2}{|c|}{ Fruit set (\%) } & \multirow[b]{2}{*}{$\begin{array}{c}\text { Pro- } \\
\text { bability }\end{array}$} & \multirow{2}{*}{$\begin{array}{l}\text { Number of seeds } \\
\text { per fruit of } \\
\text { unbagged flower } \\
\quad(n, \text { s.d. })\end{array}$} \\
\hline & $\begin{array}{l}\text { unbagged } \\
\text { (n) }\end{array}$ & $\begin{array}{l}\text { bagged } \\
\text { (n) }\end{array}$ & & \\
\hline platypetala & $8.0(25)$ & $9.1(55)$ & 0.620 & $14.8(12,5.0)$ \\
\hline korthalsii & 36.4 (11) & 0.0 (9) & 0.068 & $18.0(11,8.7)$ \\
\hline talangensis & 20.0 (5) & 0.0 ( 8 ) & 0.385 & $13.3(4,3.87)$ \\
\hline eubotrya & 42.2 (19) & $4.5(22)$ & 0.005 & $4.7(3,0.58)$ \\
\hline
\end{tabular}

Impatiens korthalsii and I. talangensis were self-incompatible (Table 6). While fruit sets of I. eubotrya and I. platypetala were not zero, seed sets of them were zero. All the species cultivated in Japan were self-incompatible. Fruit set in the field was positively correlated with the probability that a flower was visited by a pollinator at least once $(r=0.4, p>0.05)$.

\section{DISCUSSION}

The four Impatiens showed two contrasting pollination syndromes: sphingophily and melittophily. Impatiens platypetala was visited by crepuscular hawkmoths and had pink flowers with long filiform spurs that produced dilute nectar ( $26 \%$ sugar concentration). Impatiens korthalsii, I. talangensis and I. eubotrya had yellow flowers with long gradually tapering spurs that produced nectar of medium sugar concentration (38\%) mainly in daytime and were visited by long-tongued bees (T. asianum, A. sumatrana and E. impatiens) (Fig. 9). The higher nectar production rates by I. talangensis and I. eubotrya than I. korthalsii may be related to the larger sizes of the presumed pollinators (Anthophoridae vs. Halictidae). The higher rates of nectar robbing by Amegilla andrewsi and Protomelissa vulpecula may be another factor to increase their nectar production. But essentially the spur morphology and its maching to proboscis may ultimately determine which types of flowers are visited by bees (Roubik $e t$ al., 1985).

The yellow species, I. korthalsii, I. talangensis and I. eubotrya are endemic to Sumatra, whereas I. platypetala is widely distributed from Malay to the Lesser Sunda Archipelago (Grey-Wilson, 1989; Hotta, 1989). Flowers of the two yellow species, I. korthalsii and I. talangensis, are symmetric, but those of $I$. eubotrya are twisted and asymmetric. These flower morphologies regulated the position on pollinators' bodies to which pollen grains attach. Thus, they could use the same bee species as pollen carriers as discussed below.

The three long-tongued bee species pollinated the three yellow flower species. Thrinchostoma asianum visited only I. korthalsii, Amegilla sumatrana visited I. korthalsii and I. eubotrya, and Elaphropoda impatiens visited all three plants. Although the three sympatric yellow Impatiens species shared pollinators, the morphology of flowers separated the position of pollen attachment on pollinators. Both symmetric flowers (I. korthalsii and I. talangensis) shared a common pollinator, E. impatiens, whereas $I$. korthalsii seemed to have more restricted relations with T. asianum, and was seldom visited by A. sumatrana. The reproductive isolation of these three Impatiens species due to pollination process might be incomplete.

Okada (1989) reported that these three Impatiens species had different chromosome numbers: $I$. korthalsii $2 \mathrm{n}=14(2 \mathrm{x})$; I. eubotrya, $2 \mathrm{n}=28(4 \mathrm{x})$; I. talangensis, $2 \mathrm{n}=\mathrm{ca} .60$ (8x?). The 


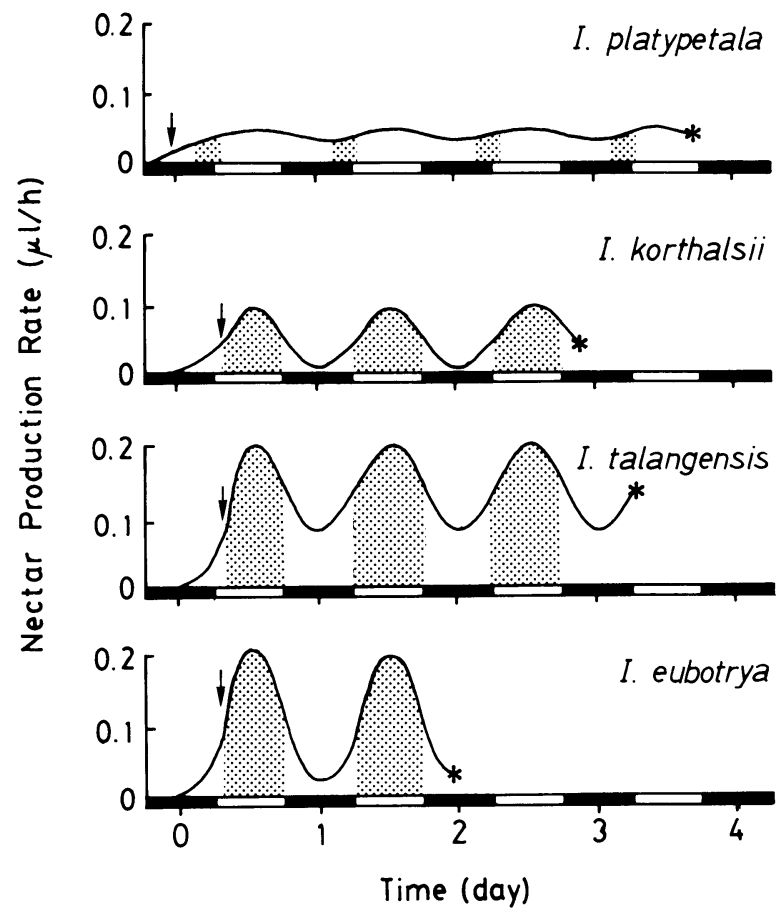

Fig. 9. Temporal patterns of flowering, nectar production of the four Impatiens species and insect visits (shaded areas) to them. Solid and open scales denote night and daytime, respectively. Opening and dropping of flowers are shown by arrows and asterisks, respectively.

polyploidy is the main cause of the reproductive isolation. At the study site in Alahanpanjang, there were other Impatiens species which were thought to be very close to I. korthalsii and I. talangensis but had different chromosome numbers (rheophilous $I$. diepenhorstii and ridge growing $I$. beccarii; both $2 \mathrm{n}=28$ ). The high diversity of Impatiens species in Sumatra (GreyWilson, 1980) should be studied from the standpoints of habitat segregation, polyploidy and pollinattion syndrome on regional and local scales.

The frequency of pollinator visits per day was much less in the Sumatran species than the Japanese species I. textori which is pollinated by bumblebees (Kato, 1988). The flowering span of the former (1.8-4.1 days) is equal or longer than the Japanese species (1.8 days, Kato, 1988). In spite of the low frequency of pollinator visitation, the outbreeding ratio of the Sumatran Impatiens species seemed to be high due to the extended flowering time.

Neotropical long-tubed flowers of Apocynaceae, Bignoniaceae, Convolvulaceae, Gesneriaceae, Leguminosae, Marantaceae, Polygalaceae, Rubiaceae, Verbenaceae and Zingiberaceae are pollinated by long-tongued euglossine bees (Janzen, 1971; Dressler, 1982; Roubik, 1989). In the palaeotropics, long-spurred or long-tubed flowers of Balsaminaceae, Gesneriaceae and Zingiberaceae are pollinated by long-tongued anthophorids, especially Amegilla (Kato et al., 1989). Although detailed information on their behavior is lacking, some females and males of Amegilla seem to trapline as do euglossine bees. Some neotropical understory herbs of Costus spp. (Zingiberaceae) share common pollinators due to floral convergence or conservatism to compensate for low frequency of euglossine bee visitation (Schemske, 1981). Sumatran Impatiens spp. might have unusually long flower life and similarity in floral morphology to other species due to such limitations in pollinator availability. Patterns of nectar production (peak in daytime) and nectar sugar concentration (33-37 \%) of Costus spp. (Schemske, 1981) are also similar to those of Sumatran Impatiens. In spite of differences between the continents and their pollinators (Euglossini, Apidae vs. Anthophorini, Anthophoridae), the pollination ecology of long-spurred and long-tubed flowers can be similar between the neotropics 
and palaeotropics.

In 'short-tongued' bees the enormously elongated mouthparts have been known in Colletidae and Andrenidae from Australia and New Guinea (Houston, 1983) and temperate America (LaBerge, 1978; Laroca \& Almeida, 1985). The long proboscis of the newly discovered $T$. asianum is the first example of such mouthparts in Halictidae in Southeast Asia (Sakagami et al., 1991). Elongation of the proboscis of this halictid may be a secondary adaptation to longspurred or long-tubed flowers that had coevolved with other partners, e.g., long-billed nectarinid birds in Australia and the long-tongued anthophorid bees in Sumatra.

ACKNOWLEDGMENTS We are grateful to Dr. I. Abbas, Dr. S. Salmah, Mr. R. Tamin and Dr. A. Bakar (Andalas University) for their kind arrangement during our field work, to Dr. S. Nakano (Hiroshima Shudo University), Dr. H. Okada (Osaka University) and Dr. T. Kohyama (Kyoto University) for their kind help and encouragement. We are greatly indebted to Dr. S. Riswan (Herbarium Bogoriense) for his kind permission to examine herbarium specimens. We also thank Dr. S. F. Sakagami (Hokkaido University), Dr. Sk. Yamane (Kagoshima University) and Dr. H. Inoue (Otsuma Woman's University) for identifying Apoidea, other Hymenoptera and Sphingidae, respectively. Cordial thanks go to Dr. D. W. Roubik (Smithsonian Tropical Research Institute) for reviewing the manuscript. Permission to work in Sumatra was granted by the National Scientific Institute Indonesia (LIPI). This research was supported by the International Scientific Research Program from Ministry of Education, Science and Culture, Japan (No. 62041048 for 1987 and 63043043 for 1988).

\section{REFERENCES}

Ackerman, J. D. 1985. Euglossine bees and their nectar hosts. In W. G. D'Arcy \& M. D. Correa A. (eds), The Botany and Natural History of Panamá, 225-233. Missouri Botanical Garden, St. Louis.

Brooks, R. W. 1988. Systematics and phylogny of the anthophorine bees (Hymenoptera; Anthophoridae; Anthophorini). University of Kansas Science Bulletin 53: 436-575.

Darwin, C. 1862. The Various Contrivances by which Orchids are Fertilised. Murray, London.

Dressler, R. D. 1982. Biology of the orchid bees (Euglossini). Annual Review of Ecology and Systematics 13: 373-394.

Grey-Wilson, C. 1980. Impatiens of Africa. A. A. Balkema, Rotterdam.

- 1989. A revision of Sumatran Impatiens. Studies in Balsaminaceae VII. Kew Bulletin 44: 67-106.

Hooker, J. D. 1875. Flora of British India 1: 440-483. L. Reeve, Kent, England.

Hotta, M. 1989. Identification list of Impatiens (Balsaminaceae) in West Sumatra and G. Kerinci area. Occasional Papers of the Kagoshima University Reserch Center for the South Pacific no. 16: 59-66.

Houston, T. F. 1983. An extraordinary new bee and adaptation of palpi for nectar-feeding in some Australian Colletidae and Pergidae (Hymenoptera). Journal of Australian Entmological Society 22: 263-270.

Inoue, T., Salmah, S., Sakagami, S. F., Yamane, Sk. \& Kato, M. 1990. An analysis of anthophilous insects in central Sumatra. In Sakagami, S. F., Ohgushi, R. \&Roubik, D. W. 
(eds), Natural History of Social Wasps and Bees in Equatorial Sumatra, 175-200. Hokkaido University Press, Sapporo.

Inouye, D. W. 1980. The terminology of floral larcency. Ecology 61: 1251-1253.

Janzen, D. H. 1971. Euglossine bees as long-distance pollinators of tropical plants. Science 171: 203-205.

Kato, M. 1988. Bumblebee visits to Impatiens spp.: pattern and efficiency. Oecologia 76: 364-370.

—, Itino, I., Hotta, M., Abbas, I. \& Okada, H. 1989. Flower visitors of 32 plant species in West Sumatra. Occasional Papers of the Kagoshima University Research Center for the South Pacific no. 16: 15-31.

LaBerge, W. E. 1978. Andrena (Callandrena) micheneriana, a remarkable new bee from Arizona and Mexico (Apoidea: Andrenidae). Journal of Kansas Entomological Society 51: 592-596.

Laroca, S. \& Almeida, M. C. 1985. Adaptão dos palpos labiais de Niltonia virgilii (Hymenoptera, Apoidea, Colletidae) para coleta de néctar em Jacaranda puberula (Bignoniaceae), com descrição do macho. Revista Brasileira de Entomologia 29: 289-297.

Lieftinck, M. A. 1944. Some Malaysian bees of the family Anthophoridae. Treubia hors série: 57-139.

Miquel, F. A. W. 1862. Sumatra, Zijne Plantenwereld, 395-398. C. G. van der Post, Amsterdam.

Okada, H. 1989. Chromosome counts of some plants collected from West Sumatra. Occasional Papers of the Kagoshima University Research Center for the South Pacific no. 16: 11-14.

Ridley, H. N. 1922. The Flora of the Malay Peninsula 1: 335-339 (Balsaminaceae). A. Asher \& Co., Amsterdam.

Roubik, D. W. 1989. Ecology and Natural History of Tropical Bees. Cambridge University Press, Cambridge.

Rust, R. W. 1979. Pollination of Impatiens capensis: pollinators and nectar robbers. Journal of Kansas Entomology Society 52: 297-308.

Sakagami, S. F., Kato, M. \& Itino T. 1991. Thrinchostoma (Diagonozus) asianum sp. nov.: Discovery of an african subgenus of long-malared halictine bees from Sumatra, with some observations on the oligotrophy to Impatiens. Tropics 1: 47-56.

Salmah, S., Inoue, T. \& Sakagami, S. F. 1990. An analysis of apid bee richness (Apidae) in central Sumatra. In Sakagami, S. F., Ohgushi, R. \& Roubik, D. W. (eds), Natural History of Social Wasps and Bees in Equatorial Sumatra, 139-174. Hokkaido University Press, Sapporo.

Schemske, D. W. 1981. Floral convergence and pollinator sharing in two bee-pollinated tropical herbs. Ecology 62: 946-954.

Van Steenis, C. G. G. J. 1972. The Mountain Flora of Java. E. J. Brill, Leiden. 222 pp.

Received January 15, 1991

Accepted April 20, 1991 
加藤真，市野隆雄，堀田満，井上民二 スマトラ産ツリフネソウ属 (Impatiens) 4種のスズ メガとハナバチによる送粉

インドネシア国スマトラの熱帯山地多雨林において, 同所的に生育するッリフネンウ属 (Impatiens, ツリフネソウ科) 4 種の開花様式と送粉様式を比較した. Impatiens platypetalaの 淡紅紫色の花は, 細長く垂れ下がった距に糖分 $26 \%$ の花蜜を昼夜にわたって分泌し，薄暮活動 性のスズメガ(Macroglossum corythus)によって送粉されていた. Impatiens korthalsii， I. talangensis, I. eubotrya の黄色の花は, 先細りの距に34-37\%の糖を含有する花蜜を主に昼間に分泌 し, 特殊化した長舌のコシブトハナバチの 2 種と異常に長舌になったコハナバチの 1 種によっ て送粉されていた，花の距の形態は，送粉者が花蜜への到達できるかどうかを決定していた。 ハナバチ媒の 3 種の Impatiens は 3 種のハナバチを一部共有していたが, ハナバチの体表の花 粉付着場所を違えることによって送粉者を使い分けていた４種のImpatiens は開花期間の延 長によって，送粉者の低い訪花率を補っていた．盗蜜が東南アジアで初めてケブカハナバチ科 の 2 種で観察された. 